Children's and Youths' Perspectives on Value Diversity in Education : Implications for Teacher Education and Educator Professionalism

\title{
Kuusisto, Arniika
}

Brill

2021

Kuusisto , A \& Kallioniemi , A 2021, Children's and Youths' Perspectives on Value Diversity in Education : Implications for Teacher Education and Educator Professionalism . in E Kuusisto , M Ubani , P Nokelainen \& A Toom (eds), Good Teachers for Tomorrow's Schools : Purpose, Values, and Talents in Education. Moral Development and Citizenship Education , vol. 16 , Brill , Leiden , pp. 129-147 . https://doi.org/10.1163/9789004465008_008

http://hdl.handle.net/10138/340815

https://doi.org/10.1163/9789004465008_008

unspecified

acceptedVersion

Downloaded from Helda, University of Helsinki institutional repository.

This is an electronic reprint of the original article.

This reprint may differ from the original in pagination and typographic detail.

Please cite the original version. 
Please only cite the original published version:

Kuusisto, A. \& Kallioniemi, A. (2021) Children's and youths' perspectives on value diversity in education: Implications for teacher education and educator professionalism. In E Kuusisto, M Ubani, P Nokelainen \& A Toom (Eds.) Good teachers for tomorrow's schools: purpose, values, and talents in education, Moral Development and Citizenship Education, Vol. 16, 129-147. Brill | Sense. https://doi.org/10.1163/9789004465008.

\title{
Children's and Youths' Perspectives on Value Diversity in Education
}

\section{Implications for Teacher Education and Educator Professionalism}

Arniika Kunsisto ${ }^{1}$ and Arto Kallioniemi ${ }^{2}$

Stockholm University, ${ }^{1}$ University of Helsinki ${ }^{1,2}$

\begin{abstract}
This article examines Finnish children's and youths' perspectives on encountering value diversity in education. Our examination builds on an ecological approach (e.g. Bronfenbrenner 1979; 2005; Sameroff 2010) to learning and development along individual life trajectories (e.g. Kuusisto 2011; Kuusisto \& Gearon 2017a; Lamminmäki-Vartia et al. 2020). The empirical findings presented here are based on various mixed methods data sets gathered from children, youths, parents, and professionals, in which our main focus is on the age groups 9 to 10,12 to 13 , and 15 to $16(\mathrm{~N}=2781)$ in Estonia, Finland and Sweden, and in particular the Finnish sub-sample of 1,301 children. This article presents a synthesis across a set of empirical studies, highlighting children's and youths' own perspectives encountering diversity in education. We conclude by discussing children's and youths' value learning trajectories in a changing Finnish society, and how the results can be used to inform teacher education programs and teachers' professional development on (super)diversity in school, thereby contributing to our
\end{abstract}


understanding of educating good teachers for tomorrow's schools and the role of values in education.

\section{Keywords}

Children, Youths, Education, Diversity, Value Learning Trajectories, Teacher Professionalism

\section{Introduction}

This article examines Finnish children's and youths' perspectives when encountering value diversity in education. Our examination builds on an ecological approach (e.g. Bronfenbrenner 1979; 2005; Sameroff 2010) to learning and development along individual life trajectories (e.g. Kuusisto 2011; Kuusisto \& Gearon 2017a; Lamminmäki-Vartia et al. 2020). By values we refer to the individual or group level aims, goals and life guiding principles that are consistent across situations and contexts (Schwartz 1992; 1997; 2012; Kuusisto \& Gearon 2017b) - to put simply, what is regarded as important and valuable. Worldview is here understood, again both at individual and group levels, as the ontological, epistemological and ethical orientation to the environment (Riitaoja, Poulter \& Kuusisto 2010); the ontological foundation for values, beliefs and knowledge used in meaning-making and for making choices (Poulter 2013). Furthermore, worldviews function as a philosophy of life, which plays a critical role in understanding reality and in providing satisfying meanings to life questions. As group values and epistemologies, these function to define understandings of what can be known and how to construct ideas of oneself and "the other" (Poulter, Riitaoja \& Kuusisto 2016, 68).

Worldviews are here used for both religious and non-religious traditions and approaches to meaning-making or value systems at the group level. At the individual level, especially as regards the younger generations of children and youths, worldviews are increasingly hybrid in nature, merging elements from a variety of religious, secular, etc. sources or traditions (Helve 2016). Although the present examination focuses on "value diversity" as in how children and 
youths perceive and, indeed, "encounter" different group level worldviews, we acknowledge the diversities within these traditions, as well as the necessarily oversimplified operationalizations of these complex phenomena into survey measures in order to be completable by children as young as nine in our youngest samples.

The landscape of values and worldviews in Finnish society has in recent years changed remarkably, both due to increased migration but also due to the polarization of values and worldviews more broadly. For example, Finnish society is becoming increasingly secularized, with a decreased interest in membership of institutional religions. At the same time, there is increased interest in new religious movements and spirituality. Religious socialization in the homes, as in intentional home education aiming to transmit a particular religious tradition and value system, has decreased notably (see e.g. TervoNiemelä 2020). This marks a significant change for the younger generations of children and youths who thereby construct their worldviews increasingly from a number of different sources rather than growing into a particular tradition (e.g. Kuusisto 2011), and are thus also likely to draw more influences from sources outside the family. One of our data sets informed us that alongside family, school and the Internet were the top three influencers for children and youths when searching for information about religions (Kuusisto \& Kallioniemi 2015). This diversification of worldviews and values is also a part of the everyday in societal educational arenas, where especially the big cities now host a much more varied landscape of religious and non-religious worldviews than just a couple of decades ago. These changes have implications concerning the role of values education and education on religions and worldviews in ECEC and schools.

Finland was one of the 24 participating countries in the International Civic and Citizenship Education study (ICCS) 2016. The Finnish sample included 179 comprehensive schools, some 3,200 eighth-grade students and 2,200 teachers. As regards the measured attitudes on equality and diversity, Finnish teenagers' attitudes to gender equity was on average more positive than in the participating countries. When it comes to equity between ethnic groups, the Finnish responses were on a level with the international average. Girls' attitudes were more positive than the boys'. Attitudes to equity of both genders and ethnic groups were also associated with the level of the youths' civic knowledge and cognitive test results: the higher the results, the more positive the attitudes were. Both in Finland and in the participating countries on average, the attitudes towards equity had become more positive between 
2009 and 2016 (International Civic and Citizenship Study ICCS (2017; University of Jyväskylä 2018).

Emerging diversity-related teacher professionalism through value learning

Through several empirical life history approaches and/or learning trajectory mixed methods data sets (see Table 1), we have analyzed the processes of value learning (also as a means to emerging professionalism), and developed a working model that has thereafter been used as an analytical tool (Kuusisto \& Gearon 2017a). Our focus has spanned from early childhood education, school, and teacher education to parents and home education and religious communities.

Building on previous research on teacher professionalism (e.g. Karila 2008; Rissanen et al. 2018), an ecological systems theory approach (e.g. Bronfenbrenner 1979; 2005; Sameroff 2010) and our empirical analyses, we have developed an analytical model for examining individual value learning trajectories (e.g. Kuusisto \& Gearon 2017a; 2017b; 2019; Gearon \& Kuusisto 2017a, 2017b). The model encompasses six value learning trajectory staging posts, namely: Givens, Positionings, Engagements, Tensions, Negotiations, Resolutions, and, as a result of this value negotiation process, the now altered "Givens" with more informed knowledge for further encounters of similar professional value tensions or the like (Gearon \& Kuusisto 2017). It can be used for examining value learning processes both in childhood and youths and among students or along professional trajectories. Besides the encountering of value tensions in the specific learning context, it is important to acknowledge the particular broader socio-historical and political context in which the learning context is embedded, as well as the temporality of both the learning-in-time as well as the continuously altering, also diversifying social and societal, and broader global situation. Value learning is situated in relation to societal diversity of values and worldviews, which is reflected, for instance, in the emerging teacher student professionalism in teacher education as a process of professional development through value learning (Lamminmäki-Vartia et al. 2020; Kuusisto \& Gearon 2019) and teachers' professional trajectories (e.g. Luodeslampi, Kuusisto \& Kallioniemi 2019). 
Later empirical analyses have further contributed to the proof of the concept for, and application of, the model of worldview diversity related to teacher

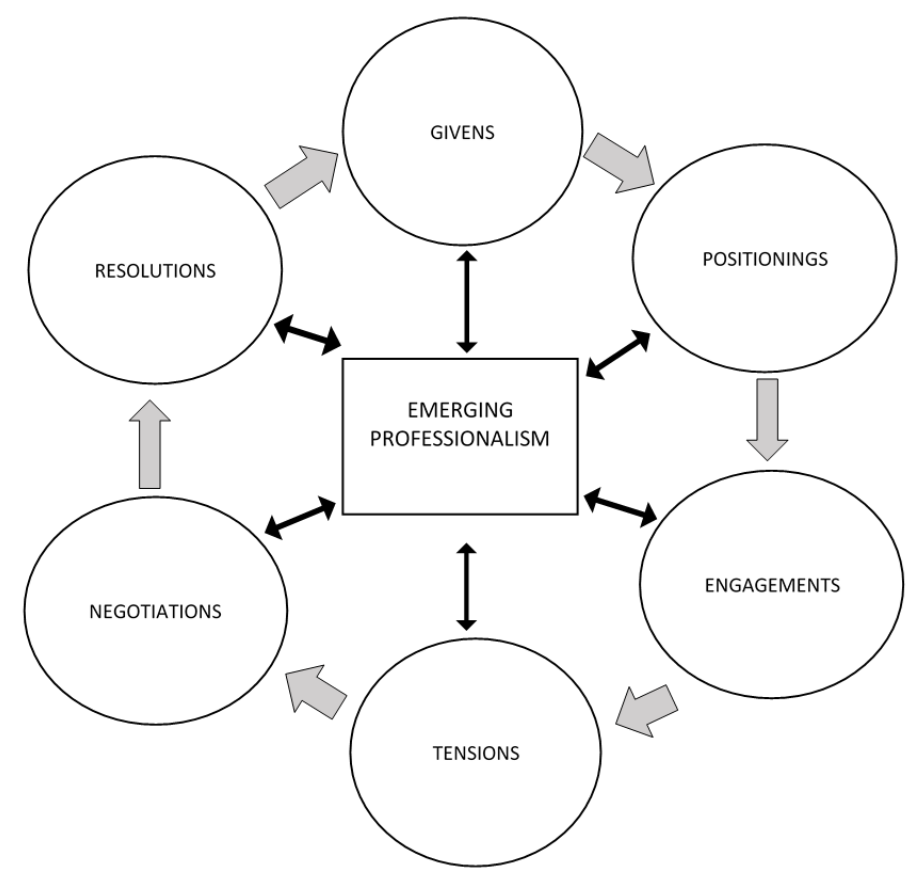

professionalism (see Figure 1) (Lamminmäki-Vartia et al. 2020).

FIGURE 1 Emerging professionalism through value learning trajectories (LamminmäkiVartia et al. 2020, on the basis of Kuusisto \& Gearon 2017a).

The figure illustrates how, drawing from student teachers' learning trajectory data (pre-survey, a 6-month process of collaborative learning in a group and as paired with a more experienced in-service teacher, and finally a retrospective interview), the emerging worldview diversity related professionalism develops gradually through the learning process (Lamminmäki-Vartia et al. 2020).

In this article, we discuss the usability of the model in the examination of children and young people's value learning related to worldview diversity in their everyday educational contexts.

Empirical findings on encountering diversity in the everyday of children and youths 
TABLE 1 Selection of empirical studies used in the present examination

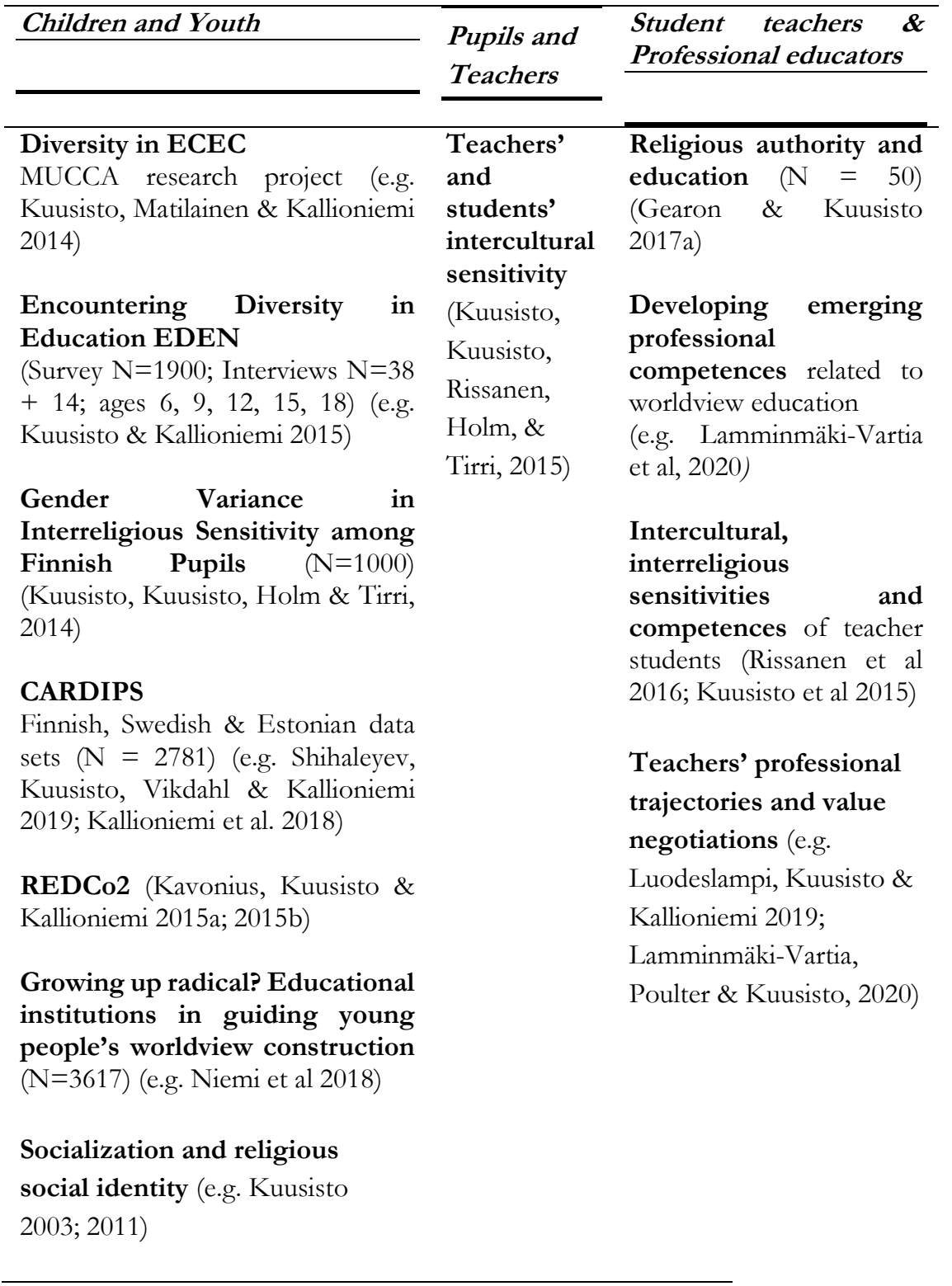

Table 1 presents a selection of the empirical analyses we have carried out in relation to encountering diversity and individual value learning trajectories. Initially, the EDEN project builds on the research strand originating with Kuusisto's study on value learning trajectories in relation to religious minority 
socialization (Kuusisto 2011), and a 2008-2010 research project Multicultural Children and Adults in ECEC (MUCCA), a joint venture between the City of Helsinki Social Services Department (Director Eija Bergman) and the ECEC research unit (Director Mikko Ojala) at the University of Helsinki, which she was responsible for carrying out (Kuusisto 2010). The project was initiated by the ECEC practitioners, who pointed out the need to locate and further develop good practices related to the then speedily diversified Finnish ECEC. The findings of this MUCCA project led to the realization of a lack of up-todate knowledge on children's and youths' perspectives on encountering the changing societal situation and increasing diversity also in the older age groups of comprehensive school pupils. A further project design was developed, now working together with Kallioniemi, to gather mixed methods data ( $=1301)$ from the ages 9, 12, and 15. Later on, the EDEN research project was first expanded internationally to the collaboration with colleagues at Södertörn University (CARDIPS project, with Straarup, Berglund 2011-2012, Vikdahl 2012-2020, Jahnke 2012-2019) and the University of Tartu (Shihaleyev), spanning across Finnish, Swedish and Estonian schools with a similar mixed methods design of an international survey instrument $(\mathrm{N}=2781)$ and interviews with children and youths in Sweden and Estonia as well as teacher interviews. The lower secondary school data was combined for some analyses together with Elina Kuusisto, Kristiina Holm, and Kirsi Tirri, for looking at the gender variance of pupils' interreligious sensitivity $(\mathrm{N}=1000)$, as well as for comparing Finnish teachers' $(\mathrm{N}=1008)$ and students' $(\mathrm{N}=1000)$ responses to a 23-item Intercultural Sensitivity Scale Questionnaire (ICSSQ). The Finnish EDEN project was also supplemented with further data gathering with upper secondary school pupils, age group 16-19. The EDEN project has also been succeeded by the presently ongoing Academy of Finland funded "Growing up radical? The role of educational institutions in guiding young people's worldview construction” (2018-2023; PI A. Kuusisto with L. Gearon, S. Benjamin, and P. Koirikivi; and L. Malkki and A. Kallioniemi as advisory members of the project) looking into the role of schools in supporting pupils' ( $\mathrm{N}=3617)$ worldview construction, and in preventing and counteracting extremism and radicalization.

Although the perspectives and research focus vary across data sets, each of these projects contributes towards a further understanding on "diversifying diversities" (Vertovec 2015) and how these intersectional complexities have influenced education and value learning in different contexts, plus the knowledge we can draw from these in developing teacher education for diversities. 
Children's and youths' experiences on diversity in educational contexts

Most pupils agreed that religion has at least an acknowledged "place" in the school context. The question of religion's place in schools in Finland has been a much-debated issue, since Finnish society has in recent decades become notably more diversified. The state is neutral, but historically we have had two national churches in Finland: the Evangelical-Lutheran and the Greek Orthodox Church. They have had a big impact on school and education. The majority of the Finnish population $(68.7 \%)$ belong to the EvangelicalLutheran Church and 1.1\% belong to the Greek Orthodox Church and 1.7\% to other religious communities; almost one third of the population $(28.5 \%)$ do not belong to any religious communities. The number of members of the Evangelical-Lutheran Church has in recent decades been decreasing and at the same time the number of people belonging to other religious communities has been increasing (Salomäki et al. 2020, 49-50). Today the Nordic societal landscape has been described as post-Lutheran (Thurfjell 2016) or Secular Lutheran (Riitaoja et al. 2010; Poulter et al. 2016).

Pupils see religion as a very important part of life "for religious persons," and many see the role of religion in society as important. Most pupils agreed that religious symbols (wearing a veil for religious reasons, or a crucifix in a necklace) can be visible in school. Many also felt that schools should provide a place for silence, and also considered it important for school meals to include alternatives suitable for those following a diet for religious reasons.

One of the starting points for our research project Encountering Diversity in Education (EDEN) was to generate up-to-date knowledge on children's and youths' experiences on diversity in their everyday contexts, and to thereby also facilitate development of education on religions, worldviews and values in ECEC and schools. The functions and the role of religious education or education on religions and worldviews has been much debated in recent years, both in Finland and internationally. At the same time, the observation has been raised that in changing societies, citizens need a much more multisided and deep knowledge and understanding in this rapidly changing world. Multiple literacies connected to religions and worldviews are also seen as one part of general literacy in the Finnish curriculum. The perspectives connected to religions are intertwined with the processes of negotiating belonging, especially inclusion and exclusion in peer groups. These negotiations and the politics of belonging (Yuval-Davis 2006), embed intersectional influences of, for example, gender, ethnicity, language, personal worldview (as religious, secular, or hybrid), and culture. This is acutely a question related to minority 
rights, as well as Universal Human Rights and the Rights of the Child. Increasing migration, increasing transnational movement of families, and the changing population structure have made religions and worldviews in many ways more visible in the everyday of children and youths.

The Finnish approach to religious education can be seen from learning about and learning from approaches which were presented by Grimmit and Ready (1975) and further developed by Grimmit (2000). Learning about religions and worldviews thereby contributes to the multiple literacies and citizenship skills for democratic, multi-value societies. Learning from religions and worldviews relates to how education can give pupils tools with which to construct their own worldviews. In Finland, education on the diversity of religions and worldviews has been seen as a function of the school, and thereby Religious Education, or the alternative Ethics, is a separate and compulsory school subject (Kallioniemi \& Ubani 2016; Åhs 2020).

Finnish schools are a very central part of society in which different languages, cultures, identities, religions and worldviews are in interaction with each another. Schools contribute to a diverse society in which the local and global are interconnected (NCCBE 2014, 26). The teaching in the subject area proceeds according to nationally set central aims defined in the curriculum. Besides knowledge on religions, the subject area covers a wide range of topics related to values and ethical education. Previous research in values and ethics education, such as research on moral dilemmas identified by pupils (Tirri 1995) and teachers' moral and ethics (Tirri 1998; 1999; 2011; Tirri \& Kuusisto E 2017), is important in informing the future development of the subject area.

In an analysis on the findings from the data of the two older comprehensive school student groups in our EDEN data from Finland $(N=825$; age groups 12-13, 15-16), we examined their views on the place of religion both as a formal part of the National Curriculum and as a part of the social interaction and physical environment in their everyday educational context. The pupils' attitudes to the visibility of religions in school was in general rather positive, contrasted by the $15 \%$ who either agreed or agreed strongly that religion should not be visible at school. The majority (47\%) also agreed that there should be opportunities to discuss religion-related matters at school; $31 \%$ had a neutral stance to this statement, whereas a fifth $(21 \%)$ disagreed or strongly disagreed with it. The openness towards the visibility of religions differed between their peers wearing small, more discreet religious symbols, and the wearing of more visible ones, such as wearing a necklace with a cross (Likert $1-5 ; M=3.5)$, was seen much more positively than the wearing of religion- 
related clothing, such as a veil $(\mathrm{M}=3.2),(\mathrm{t}=7.1, \mathrm{df}=824)$ (Kuusisto, Poulter \& Kallioniemi, 2017.)

Both age and gender variance were present in the findings. Girls, for instance, showed more acceptance for the use of religious symbols in school than boys did: they regarded the wearing of both discreet $(\mathrm{M}=3.8, \mathrm{SD}=1.4$ vs. boys $\mathrm{M}=3.2, \mathrm{SD}=1.4)$ and visible $(\mathrm{M}=3.6, \mathrm{SD}=1.5$ vs. boys $\mathrm{M}=2.8, \mathrm{SD}=$ 1.4) religious symbols more positively. In both cases the differences were highly significant $(\mathrm{t}=5.5 * * *, \mathrm{df}=823 ; \mathrm{t}=7.5 * * *, \mathrm{df}=823)$. This is in line with previous research (Holm 2012; Kuusisto et al. 2014), suggesting that girls are more tolerant toward diversity than boys are. Boys also agreed more often than girls (almost significant difference: $\mathrm{t}=2.8 *, \mathrm{df}=823$; boys $\mathrm{M}=2.6, \mathrm{SD}$ $=1.2$ vs. girls $\mathrm{M}=2.4, \mathrm{SD}=1.2$ ) that religion should not be visible at school. Previous research also indicates that girls are more religious than boys (e.g. Francis and Robbins 2005). Age, here measured with the school grade (6th grade age group 12-13 vs. 9th grade age group 15-16), also made a difference in pupils' openness towards the visibility of religions in school. Older pupils $(\mathrm{M}=3.7, \mathrm{SD}=1.4)$ agreed more often than younger ones $(\mathrm{M}=3.4, \mathrm{SD}=$ 1.4) that one should have a right to wear at least discreet religious symbols at school. The same also applied to the wearing of religion-related clothing such as a head scarf $(\mathrm{M}=3.3, \mathrm{SD}=1.5$ vs. $\mathrm{M}=3.1, \mathrm{SD}=1.5)$-both differences were statistically significant $(\mathrm{t}=3.1 * *, \mathrm{df}=823 ; \mathrm{t}=2.4 * *$, df $=823$ ) (Kuusisto, Poulter \& Kallioniemi, 2017).

The cultural, secular nature of some of the Lutheran majority was exemplified, for instance, in the following quote from the open answers of a ninth grader: "My official religion is EvLuth. But I am an Atheist, I do not believe in God." And about parental affiliation, they state: "Evangelical Lutheran, but they do not believe in God." (9th grader, Helsinki [288]). (Kuusisto, Poulter \& Kallioniemi, 2017.)

Our international mixed methods data sets include samples from Finnish, Swedish and Estonian children and youths in the age groups of 9 to 10, 12 to 13 and 15 to 16 - a purposive non-probability sample of $\mathrm{N}=2781-$ consisted of 713 respondents from Estonia, 1,257 from Finland, and 811 from Sweden. The sampling was purposive, as the researchers were interested in schools with more notable cultural and religious diversity. The proportion of male and female respondents was almost equal (49\% and 51\%, respectively), as was the distribution between age groups (33\% for third graders, $33 \%$ for sixth graders, and $34 \%$ for ninth graders). We focused in particular on the ways in which the children perceived and encountered 
diversity in their school context, as well as how this diversity was connected with peer group inclusion and exclusion. About half of the pupils report experiences of having been either frequently or occasionally bullied: 11\% report having been bullied frequently, and $41 \%$ occasionally. The perceived preconditions for bullying were mainly connected to visible diversity, such as people's appearance (explaining $5 \%$ of frequent and $20 \%$ of occasional bullying), clothes (3\% frequent and 19\% occasional), and for who they had as friends (2\% frequent and 20\% occasional). Immigrant background (1\% frequent and $4 \%$ occasional), religion ( $1 \%$ frequent and $6 \%$ occasional), and home language $(2 \%$ frequent and $8 \%$ occasional) were also mentioned (Schihaleyjev et al. 2020).

Analysis on the country of residence showed variance in this: in Estonia, more than half of the pupils (51\%) have experienced occasional and $11 \%$ frequent bullying; in Finland, 41\% for occasional and 12\% for frequent bullying; and in Sweden, 34\% of children and youths had experienced occasional and 7\% frequent bullying. In Estonia and Finland, the children and youths reported more frequent bullying or victimization because of their appearance, friends, clothes or "something else" than their peers in Sweden. Some of the reasons were also connected to gender: girls reported more bullying related to their appearance than boys did (Schihaleyjev et al. 2020).

Although the actual frequencies in the big data regarding the bullying connected to home language, religiously more observant family background, and migration background are relatively low, we have to remember that so too are the numbers of these pupils in schools. These are in fact factors making children and youths vulnerable to bullying. Of the 1,334 students who responded to the question about their parents' worldview, 632 stated that their parents are Christians, 29 Muslim, 29 some other religion, and 485 told that they practiced no religion. As an indicator for the actual religious commitment in the Secular Lutheran (Poulter et al. 2016) North, we used the question "Have you learned to pray at home?" Children and youths from more religiously devout families were bullied more than their peers from nonreligious families in all the listed categories or preconditions behind bullying - not primarily because of religion (Schihalejev et al. 2020). In our data sets age, gender, and place of residence were important factors behind openness or prejudice, or sensitivities to diversity: the older the pupils, the more open attitudes they reported towards diversity, girls being more open and tolerant than boys, and children and youths in bigger cities being more open and tolerant than those residing in smaller cities or towns. This could be seen to support the classic intergroup contact hypothesis, initially proposed 
by Allport (1954), and the vast research base founded on that: the more opportunities for dialogue, knowledge and personal interaction, the more understanding towards difference.

In another analysis, we (Kuusisto A., Kuusisto E., Holm and Tirri, 2014) examined gender variance in interreligious sensitivity among a nonprobability sample of 1,000 Finnish lower secondary school pupils in the age group 12-16. In an analysis on the pupils' self-reported attitudes towards interreligious sensitivity, measured with the Interreligious Sensitivity Scale, the findings again illustrated significant variation between genders in pupils' interreligious sensitivity. In addition, the geographical variance between the Helsinki capital area and one of the two smaller cities, as well as the pupils' own religious affiliation influenced their interreligious sensitivity (Kuusisto A. et al. 2014).

As regards the education on religions and worldviews in school, our findings pointed out that most pupils were satisfied with the RE model they had. In an analysis of the follow-up study of the international, EU-wide REDCo study, where Finland was added to the sampling, we compared the data sets from Finnish $(\mathrm{N}=406)$ and Estonian $(\mathrm{N}=582)$ pupils (total $\mathrm{N}=988)$. Again, age was highlighted as an important variable, with the older pupils' (over 16) views about religion in school being more positive than younger pupils' (under 16 years) views. The younger pupils were also more likely to agree with a statement that learning about religion leads to conflicts in the classroom. Older pupils also rated the place of religion in school higher, as well as the role of school in them learning to have respect for everyone, whatever their religion. Older pupils agreed more on the fact that at school they had opportunities to discuss religious issues from different perspectives, and they found topics related to religions more interesting at school than younger pupils did. Older pupils were also more of the opinion that learning about religions at school helps them to understand themselves better (Kallioniemi, Schihalejev, Kuusisto \& Poulter 2018).

According to pupils, there should be objective teaching about religions and beliefs and about other outlooks on life. In diversified societies, the need for knowledge concerning different religions and worldviews has risen significantly. Present and future citizens need much larger and deeper skills in issues concerning religions and worldviews than previous generations did. In Finnish society, there are many challenges in developing the current system of religious and worldview education. At present, RE is organized according to pupils' formal membership or affiliation, if any, so the subject is taught in 
separate teaching groups. In some schools, there can be six different religious education classes (e.g. Lutheran, Orthodox, Catholic, Muslim, Buddhism, and secular ethics). The present RE model has been seen to support religious minority identities (e.g. Rissanen 2014) through "interpreting" world religions into local, "lived" religions and contexts, thereby possibly contributing towards inclusion and coherence in society, democratic citizenship, and countering extreme and radical thinking. This is where both the local variance in applying worldview education (e.g. Tainio et al. 2018 for the ECEC level) and teacher's implicit theories and moral professionalism (Rissanen et al. 2018) gain a critical role.

Discussion and open conclusion

Though merely a brief overview of selected results related to diversity in educational settings in Finland, and in particular how children and youths have experienced it in their everyday lives, there are a few points that we would like to conclude with. First of all, we would like to highlight the important role of societal educational contexts in supporting children and young people's value learning and worldview construction. This is not only due to the diminishing role of explicit religious education in families (e.g. Tervo-Niemelä 2020), but also, as the findings above show, the children and youths themselves appreciate school as a platform for learning and discussion on religions and worldviews. Secondly, we would like to highlight the diverse school context as a space and place for familiarizing oneself with the alternative ways of seeing the world. It is here that students "encounter" values, worldviews, and religions but also have an opportunity to familiarize themselves with and learn to appreciate them. This is of critical importance not only for secular, culturally Christian majority children, but also for children from minority cultural, language, and worldview backgrounds: those who are at present most vulnerable to being bullied in schools (Schihalejev et al. 2020).

What remains in a critical role is how to ensure teacher competences related to worldview diversity so that all student teachers would be equipped to deal with worldview-related sensitivities and moral professionalism. Where the school contributes to a diverse society in which the local and global are interconnected (Perusopetuksen opetussuunnitelman perusteet 2016, 26), it also needs to ensure that its understanding of Finnishness is broad enough to welcome all the "diversifying diversities" (Vertovec 2015) as a part of its perception of "us," so that the minority cultures, languages or religious will no longer trigger peer-group exclusion and bullying. Democratic citizenship education needs to start with the welcoming of diversity at the societal, school 
and classroom level. Education on religions, worldviews and values that contributes towards this end should foster an increased understanding of a variety of different "lived" perspectives, besides providing knowledge on different traditions.

As regards the implications of the above-presented findings to teacher education and beyond, these complex questions resonate with a solid body of previous research. Rissanen, Kuusisto E., Hanhimäki and Tirri (2018) have analyzed the implications of teachers' implicit theories for moral education, illustrating the multiplicity of ways in which teachers' implicit beliefs are communicated to students and also how these influence teachers' interpretations and endeavors to educate the ethical capabilities of their pupils. Rissanen et al. define moral professionalism in line with Sockett (1993) as the quality of educators' professional practices, thereby judged by professional standards and actualizing in teachers' moral practices and roles in everyday educational contexts (Hanhimäki, 2011). In their review on previous literature, they conclude that the moral dimension of teaching has been seen to include teacher positionings on moral sensitivity, moral judgment, moral motivation, moral behavior, and teachers' professional ethics and values (Bebeau, Rest, \& Narvaez, 1999; Narvaez, 2007; Rest, 1983; Tirri, Toom, \& Husu, 2013). The conclusion is that morally professional teachers need competencies related both to their character and to their conduct if they are to promote learners' holistic development (Tirri, 2011; Tirri, Husu, \& Kansanen, 1999). Based on their empirical analysis, Rissanen et al. argue for the importance of implicit theories in research on moral education (Rissanen, Kuusisto E., Hanhimäki \& Tirri, 2018).

As part of the emerging professionalism of student teachers, future teachers should be even better supported in, and equipped with, a multisided knowledge of "diversifying diversity" or superdiversity (Vertovec 2015) in society. As also our student teacher learning diaries illustrate (LamminmäkiVartia et al. 2020), teachers should also have an openness to life-long learning and continuously developing professionalism in relation to the lived worldviews of the children, families and colleagues in societal educational contexts. This also necessitates a deeper 'take' on the perspectives of (super)diversity and lived religions in teacher education (Poulter et al. forthcoming). These perspectives should, moreover, be a vital part of teacher education. Students need to be made aware of the complexity of superdiversity and lived religions as part of teacher education. Furthermore, a high level of reflexivity is needed in teacher education. It is of critical importance for student teachers and in-service teachers to understand about 
peer group sensitivity to diversity — both intercultural and interreligious - in order for them to teach about religions and worldviews sensitively.

Education without the dimensions of values and ethics is an impossibility. Questions related to ethics are accentuated in our rapidly changing society and schools, where diversifying diversities, and multiple values and worldviews, are always present. This means that teachers convey values in their work, consciously or unconsciously. Therefore, it is very important that teachers reflect on their own values and presuppositions critically. Teachers are always role models in their approach to diversity, and this is shown in how we talk about diversity and "other" religions, worldviews, traditions and cultures. The questions we need to ask are many. Do all cultures and worldviews get the same amount of time and space in classroom dialogue? Are they presented in an equally positive light? Does every pupil have the place to be seen and heard? Teachers are in a key position for constructing a positive atmosphere in education and classroom interaction, which is an important element in supporting learning (Day \& Johansson 2008; Biesta 2010; Kallioniemi \& Honkasalo \& Kuusisto 2015, 117).

Teachers develop professionalism during and after teacher education, and professional trajectories are a continuous value learning process. Professionalism is constantly being developed through experiences, thus building tacit knowledge into a personal way of dealing with diversities. Teachers should build a positively appreciative space in the classroom for respectful discussion. Their job is to encourage a positive presence for diversity, both as regards the explicit teaching of worldviews and traditions, and through their example and role model in the respectful encounter of values, worldviews, and religions different to their own.

\section{References}

Ahs, V. (2020). Worldviews and integrative education. A Case Study of Partially Integrative Religious Education and Secular Ethics Education in a Finnish Lower Secondary School Context. Helsinki Studies in Education 89. Helsinki: Yliopistopaino Unigrafia. Allport, G. W. (1954). The nature of prejudice. Addison-Wesley.

Bebeau, M., Rest, J., \& Narvaez, D. (1999). Beyond the promise: A perspective on research in moral education. Educational Researcher, 28, 18-26.

Biesta, G. 2010. Good Education in an Age of Measurement: Ethics, Politics, Democracy. Boulder, CO: Paradigm Publisher.

Bronfenbrenner, U. (1979). The ecology of human development: experiments by nature and design. Cambridge, MA: Harvard University Press. 
Bronfenbrenner, U. (2005). Making human beings human: Bioecological perspectives on human development. London: Sage.

Day, C. \& Johansson, O. (2008). Leadership with a difference in schools serving disadvantaged communities: Arenas for success. In Tirri, K (ed.). Educating moral sensibilities in urban schools. Rotterdam: Sense, 19-34.

Gearon, L. \& Kuusisto, A. (2017a) On Theory: Framing Value Learning in the Life Trajectory - Epistemology, Ethics, the Existential. In A. Kuusisto \& L. Gearon (Eds.) V alue Learning Trajectories: Theory, Method, Context. Münster: Waxmann, 11-30.

Gearon, L. \& Kuusisto, A. (2017b). On Context: Value Learning and Life Trajectories Research In Situ - Historical-Political Systems, Spectrums of Value, Biographical Positionings. In A. Kuusisto \& L. Gearon (Eds.) V alue Learning Trajectories: Theory, Method, Context. Münster: Waxmann, 161-177.

Grimmitt, M. (2000). Pedagogies of religious education: Case studies in the research and development of good pedagogic practice in RE. Great Wakering, Essex: McCrimmons. Grimmitt, M \& Read, G. (1975). Teaching Christianity in RE. Great Wakering, Essex: Mayhew.

Hanhimäki, E. (2011). Moral professionalism in interaction: Educators' relational moral voices in urban schools. Münster: Waxmann.

International Civic and Citizenship Study ICCS (2017) http:/ iccs.iea.nl/home.html (Retrieved 11/2020).

Helve, H. (2016). A longitudinal perspectives on worldviews, values and identities. Journal of Religious Education 63(2-3) DOI: 10.1007/s40839-0160021-5

Kallioniemi, A. \& Honkasalo, V. Kuusisto, A. (2015). Opettajan yhteiskunnallinen rooli moninaistuvassa koulussa. In Cantell, H. \& Kallioniemi, A. (edit.). Kansankynttilä keinulaudalla. Miten tulevaisundessa opitaan ja opetetaan? 109-125. Juva: PS-kustannus,.

Kallioniemi, A., Schihalejev, O., Kuusisto, A. \& Poulter, S. (2018). Estonian and Finnish Pupils' Experiences of Religious Issues and Views on the Place of Religion in School. Religion \& Education 45:1, 73-88, DOI: 10.1080/15507394.2017.1355176

Kallioniemi, A, Schihalejev, O, Poulter, S \& Kuusisto, A. (2017). Virolaisten ja suomalaisten nuorten käsityksiä uskonnonopetuksesta koulussa, Teologinen Aikakauskirja 122 (1) 34-46.

Kallioniemi, A. \& Ubani, M. (2016). Religious Education in Finnish School System. In H.Niemi \& A. Toom \& A. Kallioniemi (eds.) Miracle of Education 179-190. Rotterdam: Sense Publishers.

Karila, K. (2008) A Finnish viewpoint on professionalism in early childhood education. European Early Childhood Education Research Journal, 16 (2), 210-223, DOI: $10.1080 / 13502930802141634$. 
Kavonius, M., Kuusisto, A., \& Kallioniemi, A. (2015a). Religious Education and Tolerance in the Changing Finnish Society. Religious Education Journal of Australia, 31(1), 18-24.

Kavonius, M., Kuusisto, A., \& Kallioniemi, A. (2015b). Pupils' Perceptions of Worldview Diversity and Religious Education in the Finnish Comprehensive School. Journal of Intercultural Studies: an international journal, 36(3), 320-337. https://doi.org/10.1080/07256868.2015.1029884.

Kuusisto, A. (2003) Transmitting religious values in Adventist home education, Journal of Beliefs \& Values, 24:3, 283-293, DOI:

10.1080/1361767032000156066.

Kuusisto, A. (2010). Social networks and identity negotiations of religious minority youth in diverse social contexts. Ethnic and Racial Studies, 33(5), 779796. https://doi.org/10.1080/01419870903254679

Kuusisto, A. (2011) Growing up in Affiliation with a Religious Community: A Case Study of Seventh-day Adventist Youth in Finland. Munster: Waxmann

Kuusisto, A. \& Gearon, L. (2017a). The Life Trajectory of the Finnish Religious Educator. Religion and Education. 44(1), 39-53. DOI: 10.1080/15507394.2016.1272154.

Kuusisto, A. Gearon, L. (2017b). On Method: Researching Value Learning and Life Trajectories - Dialogue, Diversity and Inter-Disciplinarity. In A. Kuusisto, A. \& L. Gearon (Eds.) Value Learning Trajectories: Theory, Method, Context. Münster: Waxmann, 99-115.

Kuusisto, A. \& Gearon, L. (2019). Why Teach about Religions? Perspectives from Finnish Professionals. Religions, 10 (6) 347, DOI: 10.3390/rel10060347. Kuusisto, A. \& Kallioniemi, A. (2015). Pupils' views of Religious Education in a Pluralistic Educational Context. Journal of Beliefs and Values 35 (2), 155164.

Kuusisto, A., Kuusisto, E., Holm, K., \& Tirri, K. (2014). Gender Variance in Interreligious Sensitivity among Finnish Pupils. International Journal of Children's Spirituality 19(1), 25-44. https://doi.org/10.1080/1364436X.2014.887560.

Kuusisto, A., Kallioniemi, A., \& Matilainen, M. (2014). Monikulttuurinen työyhteisö suomalaisen varhaiskasvatuksen kentällä. Kasvatus, 45(2), 113-126. Kuusisto, A., Poulter, S. \& Kallioniemi, A. (2017). Finnish Pupils' Views on the Place of Religion in School, Religious Education, 112:2, 110-122, DOI: 10.1080/00344087.2016.1085237.

Kuusisto, E., Kuusisto, A., Rissanen, I., Holm, K., \& Tirri, K. (2015). Finnish teachers' and students' intercultural sensitivity. Journal of Religious Education, 63(2), 65-77. https://doi.org/10.1007/s40839-016-0018-0.

Lamminmäki-Vartia, S., Poulter, S. \& Kuusisto, A. (2020). Learning trajectory of emerging professionalism: Finnish student teacher negotiating worldview 
education and ECEC superdiversity. Contemporary Issues in Early Childhood. https://doi.org/10.1177/1463949120961598.

Luodeslampi, J. Kuusisto, A. \& Kallioniemi, A. (2019). Four Religious Education Teachers: Four Retrospective Career Trajectories. Religions 10 (8), 474. https://doi.org/10.3390/rel10080474.

Narvaez, D. (2007). How cognitive and neurobiological sciences inform values education for creatures like us. In D.N. Aspin \& J.D. Chapman (Eds.), Values education and lifelong learning (pp. 127-146). Netherlands: Springer.

NCCBE (2014). National Core Curriculum for Basic Education 2014. Helsinki:

National Board of Education.

Niemi, P-M., Benjamin, S., Kuusisto, A., \& Gearon, L. (2018). How and

Why Education Counters Ideological Extremism in Finland. Religions, 9 (12), 420. https://doi.org/10.3390/rel9120420.

Poulter, S. (2013). Uskonto julkisessa koulussa: koulu yhteiskunnalli-suuden näyttämönä . Kasvatus, 44 (2), 162-176.

Poulter , S. , Riitaoja , A-L. \& Kuusisto , A (2016) ' Thinking multicultural education 'otherwise' - From a secularist construction towards a plurality of epistemologies and worldviews. Globalisation, societies and education 14 (1), 68-86 . DOI: 10.1080/14767724.2014.989964.

Rest, J. (1983). Morality. In P. Mussen (Ed.), Carmichael's manual of child psychology (4th ed.). Volume on Cognitive development (J. Flavell \& E. Markman, Vol. Eds., pp. 556-629). New York, NY: Wiley.

Riitaoja, A-L., Poulter, S., \& Kuusisto, A. (2010). Worldviews and Multicultural Education in the Finnish Context: A Critical Philosophical Approach to Theory and Practices. Finnish Journal of Ethnicity and Migration, 5(3), 87-95. http://www.etmu.fi / fjem/.

Rissanen, I. (2014). Negotiating Identity and Tradition in Single-faith Religious Education: A Case Study of Islamic Education in Finnish Schools. Waxmann: Münster.

Rissanen, I., Kuusisto, E., \& Kuusisto, A. (2016). Developing teachers' intercultural sensitivity: Case study on a pilot course in Finnish teacher education. Teaching and Teacher Education, 59, 446-456. https://doi.org/10.1016/j.tate.2016.07.018.

Rissanen, I., Kuusisto, E., Hanhimäki, E. \& Tirri, K. (2018). The implications of teachers' implicit theories for moral education: A case study from Finland, Journal of MoralEducation, 47:1, 63-77, DOI: 10.1080/03057240.2017.1374244. Salomäki H., Hytönen M., Ketola K., Salminen V-M. and Sohlberg J. (2020). Uskonto arjessa ja jublassa. Suomen evankelis-luterilainen kirkeko vuosina 2016-2019. Kirkon tutkimuskeskus. Kirkon tutkimuskeskuksen julkaisuja 134. Vaasa: Grano Oy. 
Sameroff, A. J. (2010) A unified theory of development: A dialectic integration of nature and nurture. Child Development, 81, 6-22.

Schihalejev, O., Kuusisto, A., Vikdahl, L. \& Kallioniemi, A. (2020) Religion and children's perceptions of bullying in multicultural schools in Estonia, Finland and Sweden. Journal of Beliefs \& Values 41(3), 371-384, DOI: 10.1080/13617672.2019.1686732.

Schwartz, S. H. (1992). Universals in the content and structure of values: Theoretical advances and empirical tests in 20 countries. In M. P. Zanna (Ed.), Advances in experimental social psychology, Vol. 25 (p. 1-65). Academic Press. https://doi.org/10.1016/S0065-2601(08)60281-6. Schwartz, S. H. (1997). Values and culture. In D. Munro, S. Carr, \& J. Schumaker (Eds.), Motivation and culture (pp. 69-84). New York: Routledge.

Schwartz, S. H. (2012). An Overview of the Schwartz Theory of Basic Values. Online Readings in Psychology and Culture, 2(1). https://doi.org/10.9707/2307$\underline{0919.1116}$

Sockett, H. (1993). The moral base for teacher professionalism. New York, NY: Teachers College Press.

Tainio, L., Kallioniemi, A., Hotulainen, R., et al. (2019). Koulujen monet kielet ja uskonnot: Selvitys vähemmistöäidinkielten ja -uskontojen sekä suomi ja ruotsi toisena kielenä -opetuksen tilanteesta eri koulutusasteilla. Valtioneuvoston selvitys- ja tutkimustoiminnan julkaisusarja 11/2019. Helsinki: Valtioneuvoston kanslia.

Tervo-Niemelä, K. (2020). Religious upbringing and other religious influences among young adults and changes in faith in the transition to adulthood: A 10year longitudinal study of young people in Finland, British Journal of Religious Education, DOI: 10.1080/01416200.2020.1740169.

Tirri, K. (2011). Holistic school pedagogy and values: Finnish teachers' and students' perspectives. International Journal of Educational Research, 50, 159-165. Tirri, K. (1995). Ala-asteen oppilaiden identifioimien moraaliongelmien teemat ja sosiaaliset subteet. Helsingin yliopiston opettajankoulutuslaitoksen tutkimuksia; Helsinki: Yliopistopaino.

Tirri, K. (1998). Koulu moraalisena ybteisönä. Helsingin yliopiston opettajankoulutuslaitoksen julkaisuja, 187. Helsinki: Helsingin yliopisto.

Tirri, K. (1999). Opettajan ammattietiikkea. Helsinki: WSOY.

Tirri, K., Husu, J., \& Kansanen, P. (1999). The epistemological stance between the knower and the known. Teaching and Teacher Education, 15, 911-922.

Tirri, K. \& Kuusisto, E. (2017). Opettajan ammattietiikka oppimassa. Helsinki: Gaudeamus.

Tirri, K., Toom, A., \& Husu, J. (2013). The moral matters of teaching: A Finnish perspective. In Craig, C.J., Meijer, P.C. \& Broeckmans, J. (Eds.) 
Teacher Thinking to Teachers and Teaching: The Evolution of a Research Community, 223-239. Bingley: Emerald Publishing. University of Jyväskylä (2018). Finnish teenagers' civic knowledge still of high standard: Confidence in social institutions highest in the world, https://ktl.jyu.fi/en/current/news/finnish-teenagers2019-civic-knowledgestill-of-high-standard-7th-november-2017.

Thurfiell, D. (2016). Varför finns religion. Upsala: Molin \& Sorgenfrei.

Vertovec, S. (2019) Talking around super-diversity, Ethnic and Racial Studies, 42:1, 125-139, DOI: 10.1080/01419870.2017.1406128.

Yuval-Davis, N. (2006) Belonging and the politics of belonging, Patterns of Prejudice, 40:3, 197-214, DOI: 10.1080/00313220600769331. 
